\title{
Production technology and characterization of Fior di latte cheeses made from sheep and goat milks
}

\author{
M. Faccia, ${ }^{1}$ A. Trani, G. Gambacorta, P. Loizzo, A. Cassone, and F. Caponio \\ Department of Soil, Plant and Food Science, University of Bari, Via Amendola 165/A, Bari 70126, Italy
}

\begin{abstract}
Innovation in the small ruminant dairy sector faces structural challenges because dairies are often involved in breeding and produce cheeses that appeal essentially to local markets using traditional technologies and facilities. An investigation was carried out to produce Fior di latte, a traditional, soft pasta filata cheese, from sheep and goat milks at the farm level. Fior di latte is an Italian high-moisture, round mozzarella currently produced from cow and water buffalo milks; it is very popular in Europe. Cheesemaking trials were performed and the most appropriate technology proved to be a combination of direct acidification and lactic fermentation, with some modifications to the milk coagulation phase. The gross composition of the experimental cheeses was similar to that of bovine Fior di latte, and the overall hygienic quality was satisfactory even though the milk had not been pasteurized. The new cheeses were similar in appearance to the bovine type, but some specific features were detected. Besides the typical "goaty" and "sheepy" flavors, some novel and distinctive descriptors of odor, flavor, and texture were noted. Our experiment showed that good quality Fior di latte cheese that complies with microbiological requirements of the European legislation can be obtained from sheep and goat milks by appropriately modifying the cheesemaking technology.
\end{abstract}

Key words: caprine Fior di latte, ovine Fior di latte, innovative cheese

\section{INTRODUCTION}

Breeding of dairy goats and sheep is typical in marginal and less favorable (e.g., in terms of economy and climate) areas of the world. In Europe, dairy goats and sheep are concentrated in the countries bordering the Mediterranean Sea, where milk is used to produce cheese, mostly in small dairies using local and traditional methods (Scintu and Piredda, 2007). The small dairies

Received January 16, 2014.

Accepted November 10, 2014.

${ }^{1}$ Corresponding author: michele.faccia@uniba.it are often involved in breeding activities, have simple and traditional facilities, and process small amounts of milk a day. Hence, little process and product innovation has occurred in this dairy sector, even though information is available in the literature about the production of "innovative versions" of traditional sheep and goat cheeses (Kilic et al., 2009; Albenzio et al., 2010; Comunian et al., 2010). Among the Italian traditional dairy products are pasta filata cheeses, which are mainly made from cow and water buffalo milks. Some pasta filata cheeses are also made from goat and sheep milks but few reports are available in the literature about them, because they are considered minor dairy products. These products include semi-hard types such as Balkan Kashkaval (Milanović et al., 1998; Carić, 1999), and the Italian Scamorza and Vastedda (Mucchetti et al., 2008; Albenzio et al., 2013a,b), whereas soft types such as mozzarella, are not yet produced using goat and sheep milks. Bovine high-moisture mozzarella, known as Fior di latte, is very much in demand in Italy and is rapidly becoming popular throughout Europe. It is widely used as a table cheese or as an ingredient for traditional pasta dishes in restaurants, fast-food outlets, and at home. It is marketed in water or saline solutions and has a very short shelf life (from a few days to $2 \mathrm{wk}$ ) because of its high moisture content, which ranges from 60 to $67 \%$ (de Candia et al., 2007; Faccia et al., 2012; Minervini et al., 2012). Attempts have been made to prepare Fior di latte from sheep and goat milks, but the characteristics of the cheeses obtained are similar to those of low-moisture mozzarella (Shaker et al., 2012).

The purposes of our study were to (1) find a suitable technology to produce a cheese prototype from goat and sheep milks having the same characteristics as bovine Fior di latte in terms of composition and appearance; and (2) assess the main chemical, microbiological, and sensory features of the product.

\section{MATERIALS AND METHODS}

\section{Cheesemaking}

Milk for cheesemaking was taken from 2 farms in the Apulia region of southern Italy where sheep of differ- 
ent breeds (Sarda, Leccese, and Comisana) and Jonica goats were reared. The farms were officially free of brucellosis. The milk was collected after morning milking at $4 \pm 2^{\circ} \mathrm{C}$ and transported to our laboratory in 50-L stainless steel tanks. Milk temperature upon arrival was $6 \pm 1^{\circ} \mathrm{C}$ and the milk was not pasteurized. To assess the most suitable processing method, cheesemaking trials were performed using 3 different technologies: direct acidification (DA) of milk with citric acid, acidification of the curd by lactic fermentation (LA) with selected starters, and mixed acidification (direct acidification + lactic fermentation, DLA). Each trial was run in duplicate in a laboratory dairy plant consisting of $30-\mathrm{L}$ vats indirectly heated by steam; curd was cut with fixed-size nylon networks and stretched manually. Temperature and $\mathrm{pH}$ during processing were continuously controlled by a combined $\mathrm{pH}$ meter/thermometer apparatus (Crison, Barcelona, Spain). Food-grade citric acid (monohydrated) was supplied by Tecnomilk S.r.l. (Gioia del Colle, Italy); single-strength liquid calf rennet $(1: 10.000,80 \%$ chymosin, $20 \%$ pepsin) was from Chr. Hansen (Milwaukee, WI). For DA cheesemaking, a milk "stretching trial" was performed as described in a previous paper (Faccia et al., 2009) to establish an appropriate level of acidification. A 10\% citric acid solution was then added to the cool milk and, after mixing by stirring, the temperature was increased for coagulation. For the LA trials, milk was heated at $38^{\circ} \mathrm{C}$ and inoculated with a selected strain of Streptococcus thermophilus as a starter (freeze-dried culture for direct vat inoculation; CSL, Zelo Buon Persico, Italy); after $30 \mathrm{~min}$, rennet was added to induce coagulation. For the DLA trials, cool milk was partially acidified with citric acid, the temperature was increased to $38^{\circ} \mathrm{C}$, and the starter (the same strain as in the LA trial) was inoculated. The cheeses obtained from all the trials were immediately cooled after stretching by immersion in chilled water until the core temperature reached $8^{\circ} \mathrm{C}$. Then, the cheeses were salted for 10 min in a $12 \%$ brine kept at $8^{\circ} \mathrm{C}$, packaged in plastic bags, using water as governing liquid (in which the cheese is stored), and stored under refrigeration. The yields (kg of cheese/100 $\mathrm{kg}$ of milk) were calculated by weighing the cheeses 24 $\mathrm{h}$ after cooling.

Sensory screening was performed on the experimental cheeses obtained in the trials, and the technology providing the best sensory properties was chosen to produce the final prototypes from goat and sheep milks at a semi-industrial dairy plant available at one of the farms. Two batches of Fior di latte prototypes, spherical in shape and each weighing about $200 \mathrm{~g}$, were obtained and subjected to chemical, microbiological, and sensory analyses $24 \mathrm{~h}$ after manufacture.

\section{Chemical Analyses}

Milk fat and total protein were determined by the Gerber (IDF, 1981) and Kjeldahl methods (IDF, 1993), and an electrode (Crison) was immersed to measure $\mathrm{pH}$. Cheese moisture and $\mathrm{pH}$ were determined as reported by the International Dairy Federation (IDF, 1986, 1989), fat by the Soxhlet method, total protein by the Kjeldahl method, and sodium chloride by the Volhard method (AOAC International, 2000; method 935.43). The protein fractions of the milks and cheeses were characterized by electrophoresis. Samples were dissolved in $9 \mathrm{M}$ urea and loaded onto a discontinuous polyacrylamide gel in the presence of urea (urea-PAGE) as reported by Andrews (1983). The gel was stained with blue silver (Candiano et al., 2004) and, after destaining in water, it was scanned and subjected to densitometric analysis by using Quantity One software (BioRad, Hercules, CA). The lipid fraction was characterized by determining the total FA profile after extraction by the Folch method (Folch et al., 1957). Total FA analysis was performed by GC as reported by Trani et al. (2010). Briefly, the FAME were obtained by trans-esterification of about $25 \mathrm{mg}$ of each lipid sample, which had been previously dissolved in $2 \mathrm{~mL}$ of petroleum ether, and using $2 \mathrm{~mL}$ of boron trifluoride-methanol reagent (Morrison and Smith 1964). Samples were injected into a Fisons model MFC800 gas chromatograph (Fisons, Milan, Italy) equipped with a $60 \mathrm{~m} \times 0.32 \mathrm{~mm}$ i.d. and $0.5 \mu \mathrm{m}$ film thickness fused-silica capillary column (Stabilwax, Restek, Bellefonte, PA). The following conditions were applied: (1) oven $-5 \mathrm{~min}$ at $170^{\circ} \mathrm{C}$, followed by heating $\left(1^{\circ} \mathrm{C} / \mathrm{min}\right)$ to $220^{\circ} \mathrm{C}$, and held at $220^{\circ} \mathrm{C}$ for $30 \mathrm{~min}$; (2) carrier-helium $20 \mathrm{~cm} / \mathrm{s}$ at $170^{\circ} \mathrm{C} ;(3)$ injector- $250^{\circ} \mathrm{C}$, $1 \mu \mathrm{L}$; split 40:1; (4) detector-flame-ionization detector, $250^{\circ} \mathrm{C}$. All analyses were run in triplicate, and the means of the results were compared by Student's $t$-test at a $5 \%$ level of significance.

\section{Microbiological Analyses}

Milks and cheeses were analyzed to evaluate the parameters according to European Union requirements. Somatic cell counts of milks were determined by a Fossomatic counter (Foss Electric, Hillerød, Denmark); presence of Listeria monocytogenes and Salmonella spp. was evaluated according to the International Organizations for Standardization (ISO) methods 11290 (ISO, 1996) and 6579 (ISO, 2002); $\beta$-glucuronidase-positive Escherichia coli, and coagulase-positive staphylococci were counted according to ISO methods 16649 (ISO, 2001) and 6888 (ISO, 1999). For viable counts of milk and cheese, representative samples $(20 \mathrm{~mL}$ or $20 \mathrm{~g}$, 
Table 1. Average characteristics (SD in parentheses) of sheep and goat milks used for the cheesemaking trials

\begin{tabular}{lcccccc}
\hline Milk & $\mathrm{pH}$ & Fat $(\%)$ & Protein $(\%)$ & DM $(\%)$ & SCC (cells/mL) & $\begin{array}{c}\text { Total mesophilic } \\
\text { bacteria }(\mathrm{cfu} / \mathrm{mL})\end{array}$ \\
\hline Sheep & $6.62(0.02)$ & $6.2(0.1)$ & $5.3(0.1)$ & $17.6(0.3)$ & $5.9(0.5) \times 10^{5}$ & $110(40) \times 10^{3}$ \\
Goat & $6.72(0.03)$ & $4.2(0.1)$ & $3.8(0.1)$ & $14.1(0.2)$ & $8.1(1.1) \times 10^{5}$ & $2.0(1.4) \times 10^{3}$ \\
\hline
\end{tabular}

respectively) were diluted in $180 \mathrm{~mL}$ of $2 \%$ (wt/vol) sodium citrate solution and homogenized in a Waring blender (Waring Commercial, Torrington, CT). Serial dilutions were made in quarter-strength Ringer's solution and plated on specific media (Oxoid, Basingstoke, UK): total mesophilic bacteria were counted on plate count agar incubated at $30^{\circ} \mathrm{C}$ for $48 \mathrm{~h}$ (Gammariello et al., 2009); lactobacilli on de Man, Rogosa, and Sharpe (MRS) agar at $37^{\circ} \mathrm{C}$ for $48 \mathrm{~h}$ under anaerobiosis (Gammariello et al., 2009); streptococci and lactococci in M17 agar at $37^{\circ} \mathrm{C}$ for $48 \mathrm{~h}$ (Morea et al., 1999); yeasts and molds on yeast extract dextrose chloramphenicol agar at $30^{\circ} \mathrm{C}$ for $48 \mathrm{~h}$ (Romano et al., 2001); total coliforms on violet red bile lactose agar at $37^{\circ} \mathrm{C}$ for $24 \mathrm{~h}$ (Gammariello et al., 2009); enterococci on Slanetz and Bartley medium at $45^{\circ} \mathrm{C}$ for $48 \mathrm{~h}$ (Altieri et al., 2005); and Pseudomonas spp. in Pseudomonas agar base with CFC Pseudomonas selective supplement and $10 \mathrm{~mL} / \mathrm{L}$ of glycerol at $30^{\circ} \mathrm{C}$ for $48 \mathrm{~h}$ (Gammariello et al., 2009). Analyses were repeated 3 times for each sample.

\section{Sensory Analyses}

Sensory analyses were conducted by a panel consisting of 8 trained evaluators. The panelists ( 5 women and 3 men from our Food Science team) were very familiar with bovine pasta filata cheeses and had been selected based on international standards ISO 8586-1: (ISO, 1993) and ISO 8586-2 (ISO, 1994). Their task was to (1) screen the experimental cheeses for acceptability of taste and body/structure; and (2) evaluate in detail the sensory properties of the final prototypes versus a commercial sample of bovine Fior di latte produced using similar technology. Using a slightly modified version of the protocol reported by Minervini et al. (2012), the panelists rated hardness $(1=$ soft; $4=$ very hard $)$ and creaminess $(1=$ not creamy, $4=$ very creamy $)$ for body/structure, and sourness $(1=$ not sour, $4=$ very sour $)$ and flavor $(1=$ barely perceivable, $4=$ very intense) for taste. The descriptor list reported by Pagliarini et al. (1997) was used for detailed assessment of sensory properties. Preliminarily, the panelists participated in 6 training sessions to become familiar with the descriptors using the same standard materials proposed by Pagliarini et al. (1997). Then, a reference value was established for each descriptor on a commercial bovine Fior di latte taken from a dairy that used DLA technology. The panelists were asked to rate the intensity of each attribute by assigning a score of 1 (absence of the sensation) to 5 (extremely intense). After the training period, the panel assessed the samples of sheep and goat milk Fior di latte in 6 sessions, 3 for sheep and 3 for goat milk samples. In addition to rating the descriptors in the list, the panelists discussed the novel characteristics perceived and suggested some new descriptors. Data were tested for normality distribution by Kolmogorov-Smirnov's test, whereas Levene's test was used to verify the homogeneity of variance. The significant differences were tested by ANOVA with Tukey's honestly significant difference (HSD) test post hoc, for multiple comparison. All analyses were performed using software SPSS v.19 (SPSS/IBM, Armonk, NY).

\section{RESULTS AND DISCUSSION}

\section{Cheesemaking}

The microbiological and chemical parameters of milk are summarized in Table 1: SCC and TMB counts

Table 2. Results of the cheesemaking trials

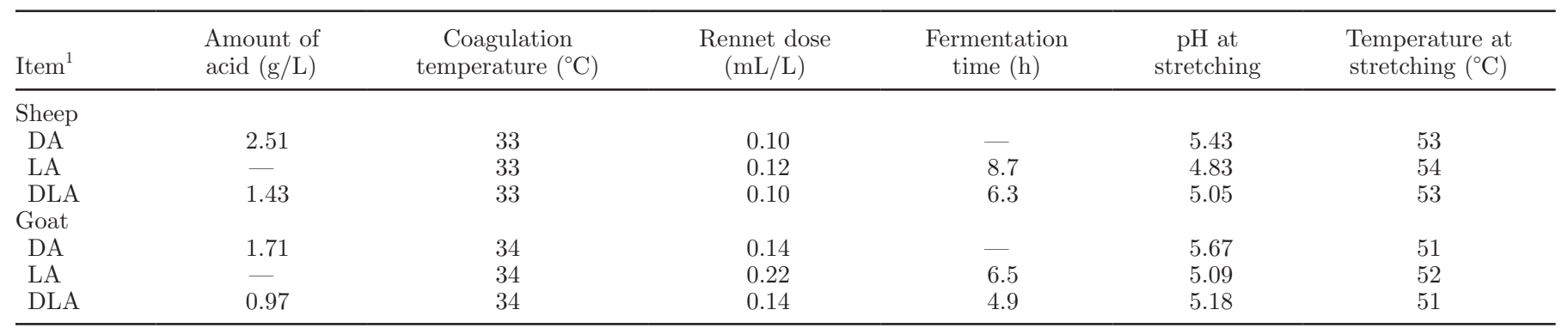

${ }^{1} \mathrm{DA}=$ direct acidification; $\mathrm{LA}=$ lactic fermentation; DLA = direct acidification + lactic fermentation. 
Table 3. Technological parameters for the production of sheep and goat Fior di latte prototypes by the direct acidification plus lactic fermentation method

\begin{tabular}{|c|c|c|}
\hline Item & Sheep & Goat \\
\hline \multicolumn{3}{|l|}{ Acidification phase } \\
\hline Temperature of milk on adding acid $\left({ }^{\circ} \mathrm{C}\right)$ & 8 & 8 \\
\hline Amount of acid used $(\mathrm{g} / \mathrm{L})$ & 1.46 & 0.94 \\
\hline $\mathrm{pH}$ after acid adjunct & 5.99 & 6.02 \\
\hline Temperature at starter inoculation $\left({ }^{\circ} \mathrm{C}\right)$ & 38 & 38 \\
\hline Starter inoculation to rennet addition (min) & 40 & 40 \\
\hline $\mathrm{pH}$ at rennet addition & 5.91 & 5.94 \\
\hline \multicolumn{3}{|l|}{ Coagulation/fermentation phase } \\
\hline Rennet dose $(\mathrm{mL} / \mathrm{L})$ & 0.10 & 0.14 \\
\hline Temperature for milk coagulation $\left({ }^{\circ} \mathrm{C}\right)$ & 33 & 34 \\
\hline Time for milk coagulation ${ }^{1}(\mathrm{~min})$ & 8 & 12 \\
\hline Rennet addition to partial drain time (min) & 43 & 48 \\
\hline Partial to final drain time (min) & 297 & 202 \\
\hline Total drain time (min) & 340 & 250 \\
\hline Final drain to stretching time (min) & 25 & 22 \\
\hline Rennet addition to stretching time $(\mathrm{h})$ & 6.08 & 4.53 \\
\hline \multicolumn{3}{|l|}{ Stretching phase } \\
\hline $\mathrm{pH}$ at stretching & 5.06 & 5.15 \\
\hline Temperature at stretching $\left({ }^{\circ} \mathrm{C}\right)$ & 55 & 52 \\
\hline
\end{tabular}

${ }^{1}$ Empirical evaluation of curd firmness.

were within the limits indicated by European Union regulations. The fat:protein ratio, which is of pivotal importance in pasta filata cheese processing, was 1.17 for sheep milk and 1.11 for goat milk. The values were close to those normally found in cow milk; therefore, the cheese milks did not require standardization. However, the high protein concentration called for some modifi- cations in the coagulation process: a lower temperature and a smaller dose of rennet were used to avoid excessive hardening of the curd. The 3 cheesemaking methods yielded different results in terms of processing times and sensory characteristics of the cheeses (Table 2 and Figure 1) but in all 3, curd stretching behavior differed from that of cheeses made from cow milk. Although our experimental design was not set up to specifically investigate rheological properties, the curd paste was more malleable and had shorter fibers than is usually observed in cow milk Fior di latte processing. The LA method required a long time to reach a suitable $\mathrm{pH}$ for stretching and produced an unacceptable structure of the cheese paste, which proved to be excessively hard and rubbery, probably because of excessive syneresis during the long fermentation phase. The DA method required a very short processing time but the sensory characteristics of the resultant cheeses were very poor. Although structure received a good rating, taste was compromised by an unpleasant sour perception, a defect caused by the excessive amount of citric acid used, which was based on the preliminary stretching trials (1.71 g/L, corresponding to $\mathrm{pH} 5.43$ for sheep milk and $2.51 \mathrm{~g} / \mathrm{L}$, corresponding to $\mathrm{pH} 5.67$ for goat milk, much higher than normally used for cow milk cheeses). We had anticipated the need for higher acidification levels because the $\mathrm{pH}$ of the stretching point is closely related to the protein content of milk, but we did not anticipate the occurrence of the sour defect. In the

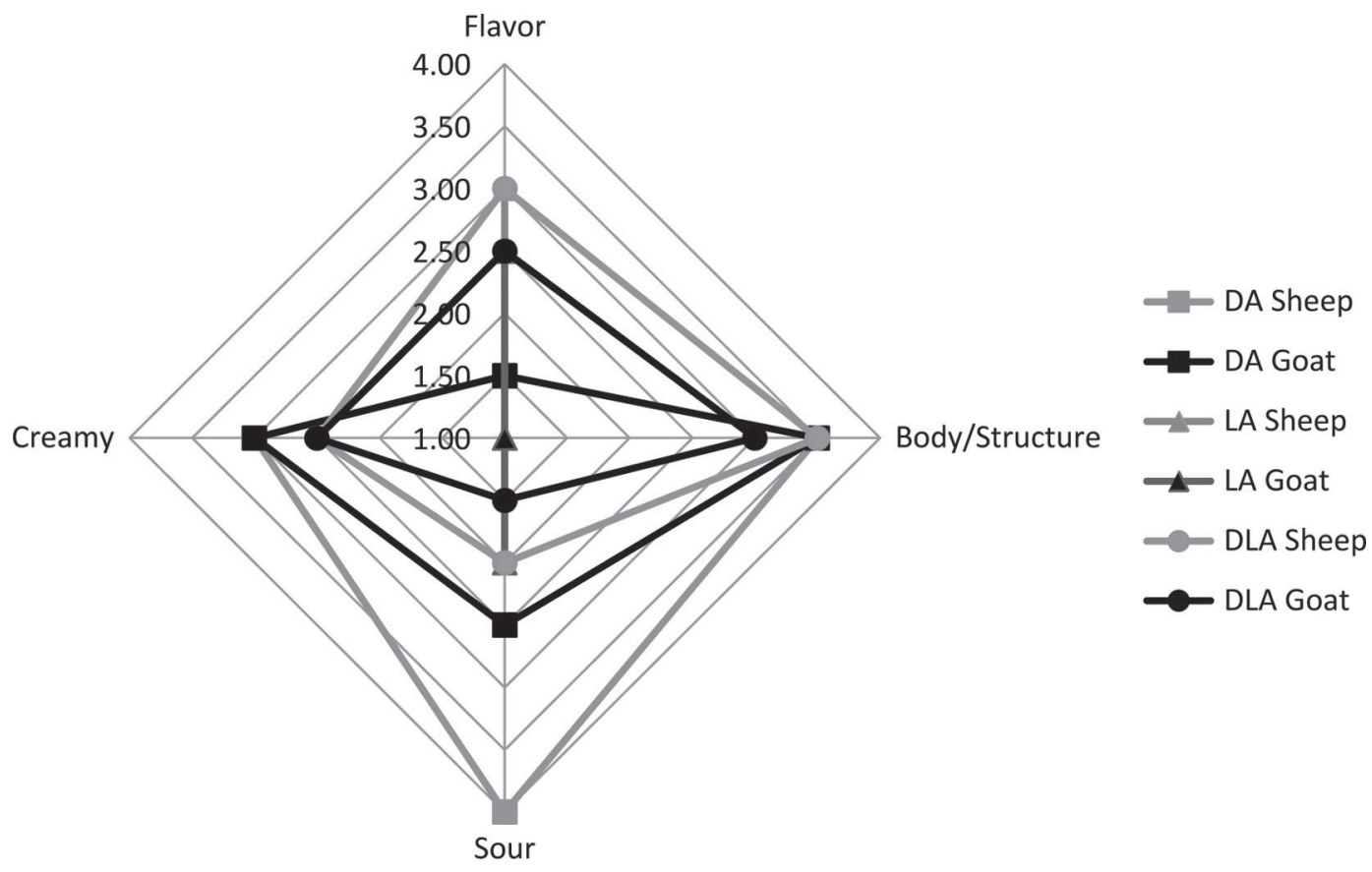

Figure 1. Sensory evaluation (on a scale from 1.00 to 4.00) of the sheep and goat cheeses obtained from the experimental trials using 3 methods: $\mathrm{DA}=$ direct acidification; $\mathrm{LA}=$ lactic fermentation; DLA = direct acidification + lactic fermentation. 
FACCIA ET AL.

Table 4. Proximate composition (SD in parentheses) of sheep and goat Fior di latte cheeses

\begin{tabular}{lllccc}
\hline Item & $\mathrm{pH}$ & Fat $(\mathrm{g} / \mathrm{kg})$ & Protein $(\mathrm{g} / \mathrm{kg})$ & $\mathrm{DM}(\mathrm{g} / \mathrm{kg})$ & $\mathrm{NaCl}(\mathrm{g} / \mathrm{kg})$ \\
\hline Sheep & $5.16(0.01)$ & $207.3(13.2)$ & $186.0(9.9)$ & $419.2(7.1)$ & $5.6(0.5)$ \\
Goat & $5.30(0.02)$ & $195.6(9.3)$ & $189.7(5.5)$ & $408.4(9.1)$ & $6.0(0.3)$ \\
\hline
\end{tabular}

sheep cheeses, the sour taste was unacceptable. The DLA technology yielded the best results, with short processing times and good sensory characteristics, and was thus deemed the most suitable of the 3 methods. It was used to produce the final prototypes of Fior di latte throughout the semi-industrial cheesemaking trials. Details are given in Table 3: cold milk was pre-acidified to $\mathrm{pH} 6.0$, and the temperature was increased to $38^{\circ} \mathrm{C}$ for starter addition. After $40 \mathrm{~min}$, the temperature was adjusted at 33 (sheep) or $34^{\circ} \mathrm{C}$ (goat) and rennet was added for coagulation. When gel firmness was judged to be satisfactory (by empirical evaluation), the coagulum was cut; the average diameter of the grains was $2 \mathrm{~cm}$ for goat and $3 \mathrm{~cm}$ for sheep. The greater dimension of the sheep curd grains was necessary to counterbalance the tendency to hardening. The curd, after sedimentation in the bottom of the vat, was kept in the whey for fermentation, and the temperature was maintained at 34 to $35^{\circ} \mathrm{C}$ by adding small amounts of warm whey when necessary. When $\mathrm{pH}$ decreased below 5.8 , a first drainage was performed and fermentation continued in about one half of the whey. After the $\mathrm{pH}$ reached 5.35, drainage was completed, and the last step of the curd fermentation took place at room temperature. Stretch-

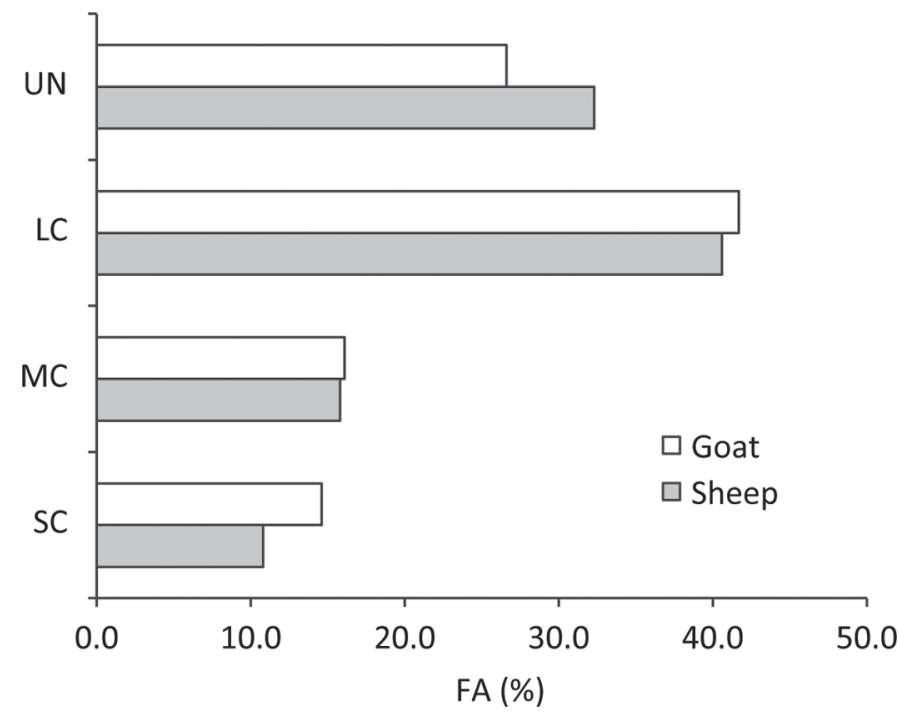

Figure 2. Fatty acid groups (\%) in sheep and goat Fior di latte cheeses. $\mathrm{UN}=$ unsaturated, $\mathrm{LC}=$ long-chain, $\mathrm{MC}=$ medium-chain, $\mathrm{SC}=$ short-chain $\mathrm{FA}$ ing was carried out by mixing the minced curd and hot water $\left(80^{\circ} \mathrm{C}\right)$ in the ratio of about 1:1 (wt:vol). No change of water was done, because the curd elongated very easily. The final $\mathrm{pH}$ of the cheeses, controlled at molding, was 5.06 and 5.15 for sheep and goat, respectively.

Unlike cow milk Fior di latte, which is salted during stretching, the prototypes were salted by immersion in $12 \%$ brine for $10 \mathrm{~min}$ at $8^{\circ} \mathrm{C}$. This modification was necessary because the curd fibers broke during stretching when using salted water $(1.5 \% \mathrm{NaCl})$ or adding salt to the milled curd before stretching $(30 \mathrm{~g}$ of NaCl$/$ $\mathrm{kg}$ of curd). The use of $12 \%$ brine was established after unsuccessful trials in $22 \%$ brine at $10^{\circ} \mathrm{C}$; under the latter salting condition, the surface of the products hardened and cracked after a few minutes. This was probably due to softness of the cheese paste. The same problem is observed for water buffalo mozzarella, which is traditionally salted in dilute brine (10-18\%). Reusing the $12 \%$ brine could pose microbiological risks, whereas preparing fresh brine for every batch of cheese could be expensive and time consuming. In our study, we prepared $12 \%$ brine by diluting the concentrated brine available at the dairy.

Table 5. Fatty acids profile (g/100 g of total FA) of sheep and goat Fior di latte cheeses

\begin{tabular}{lcc}
\hline FA & Sheep & Goat \\
\hline C4:0 & $1.32^{\mathrm{a}}$ & $0.65^{\mathrm{b}}$ \\
C6:0 & 1.23 & 1.35 \\
C8:0 & 2.33 & 2.83 \\
C10:0 & $5.87^{\mathrm{a}}$ & $9.93^{\mathrm{b}}$ \\
C12:0 & 3.98 & 4.93 \\
C13:0 & 0.09 & 0.12 \\
C14:0 & 11.75 & 11.13 \\
C14:1 & 0.23 & 0.16 \\
C15:0 & 1.39 & 0.89 \\
C16:0 & 26.50 & 29.04 \\
C16:1 & $0.60^{\mathrm{a}}$ & $0.35^{\mathrm{b}}$ \\
C17:1 & 0.04 & 0.03 \\
C18:0 & 0.03 & 0.02 \\
C18:1 & 12.43 & 11.88 \\
C18:2 & $30.01^{\mathrm{a}}$ & $25.61^{\mathrm{b}}$ \\
C18:3 & $0.54^{\mathrm{a}}$ & $0.21^{\mathrm{b}}$ \\
C20:0 & 1.33 & 0.71 \\
\hline
\end{tabular}

a,b Means in the same row bearing different superscripts differ $(P<$ $0.05)$. 
Table 6. Microbiological profile ${ }^{1}$ of sheep and goat milks $\left(\log _{10} \mathrm{cfu} / \mathrm{mL}\right)$ and Fior di latte cheeses $\left(\log _{10} \mathrm{cfu} / \mathrm{g}\right.$; SD in parentheses)

\begin{tabular}{|c|c|c|c|c|c|c|c|}
\hline Item & LB & $\mathrm{LC}$ & $\mathrm{TC}$ & $\mathrm{EC}$ & Y\&M & TMB & Pseud \\
\hline Sheep cheese & $5.04(0.08)$ & $9.46(0.31)$ & $<2$ & $3.74(0.18)$ & $<2$ & $5.80(0.17)$ & $3.79(0.31)$ \\
\hline Goat milk & $3.88(0.10)$ & $4.15(0.11)$ & $2.48(0.08)$ & $<2$ & $<2$ & $3.30(0.15)$ & $3.83(0.05)$ \\
\hline
\end{tabular}

${ }^{1} \mathrm{LB}=$ lactobacilli; $\mathrm{LC}=$ streptococci and lactococci; $\mathrm{TC}=$ total coliforms; $\mathrm{EC}=$ enterococci; $\mathrm{Y} \& \mathrm{M}=$ yeasts and molds; $\mathrm{TMB}=$ total mesophilic bacteria; Pseud = Pseudomonas spp.

\section{Chemical and Microbiological Characteristics of Cheeses}

The composition of the cheeses is summarized in Table 4. The gross composition was relatively similar to that reported in the literature for bovine Fior di latte; the fat:protein ratio was $>1$ and the moisture content was close to $60 \%$ (Faccia et al., 2012; Minervini et al., 2012). The yields of cheese ( $\mathrm{kg}$ of cheese $/ 100 \mathrm{~kg}$ of milk) were greater than those typical for cow milk: 25.2 for sheep and 17.5 for goat, compared with 13.5 to $14 \mathrm{~kg}$ of cheese $/ 100 \mathrm{~kg}$ of milk for CM. The mean FA composition of the cheeses is shown in Table 5 and Figure 2. The FA found in greater quantities were oleic and palmitic acids, followed by myristic and stearic acids. The main differences between sheep and goat cheeses were in the short-chain group ( $\mathrm{C} 4$ to $\mathrm{C} 10)$ and the unsaturated group, with short-chain FA being higher in the goat cheese and unsaturated FA greater in sheep cheese. In detail, higher percentages of butyric (C4:0), oleic (C18:1), and linoleic acids (C18:2) were detected in sheep cheese $(P<0.05)$, whereas a higher percentage of capric acid (C10:0) was found in goat cheese $(P<$ $0.05)$. These particular FA differences found in cheese are not commonly found in milk (Park et al., 2007). Comparison with bovine Fior di latte is not feasible because no information is present in the literature, but a comparison can be made with low-moisture mozzarella (Hauff and Vetter, 2009). The same 4 FA have been reported to be the most abundant in low-moisture mozzarella, with oleic acid being second in relative quantity after palmitic acid; the ratios among the FA groups in bovine low-moisture mozzarella are different with respect to those found in the present study. The urea-PAGE patterns of caseins of milks and cheeses 1 $\mathrm{d}$ after production are shown in Figure 3. The patterns of the caseins of milk and cheese for each species were similar, and bands different from caseins were only slightly detectable in cheese, indicating that no primary proteolysis could be detected $1 \mathrm{~d}$ after production. This finding may be due to the small amount of rennet added to milk and retained in the Fior di latte paste and to partial thermal denaturation during curd stretching. As expected, the electrophoretic mobility of sheep and goat $\alpha_{\mathrm{S} 1}$-caseins was different (Veloso et al., 2002). The resolution of the casein bands was better than that described in the literature, suggesting that urea-PAGE could be used for control purposes in similar cheeses to detect and quantify mixes of goat and sheep milks, not only mixes with bovine milk (Molina et al., 2002; Veloso et al., 2002; Mallatou et al., 2004). The microbiological profiles of the prototype cheeses are shown in Tables 6 and 7 . The hygienic quality was satisfactory, as none

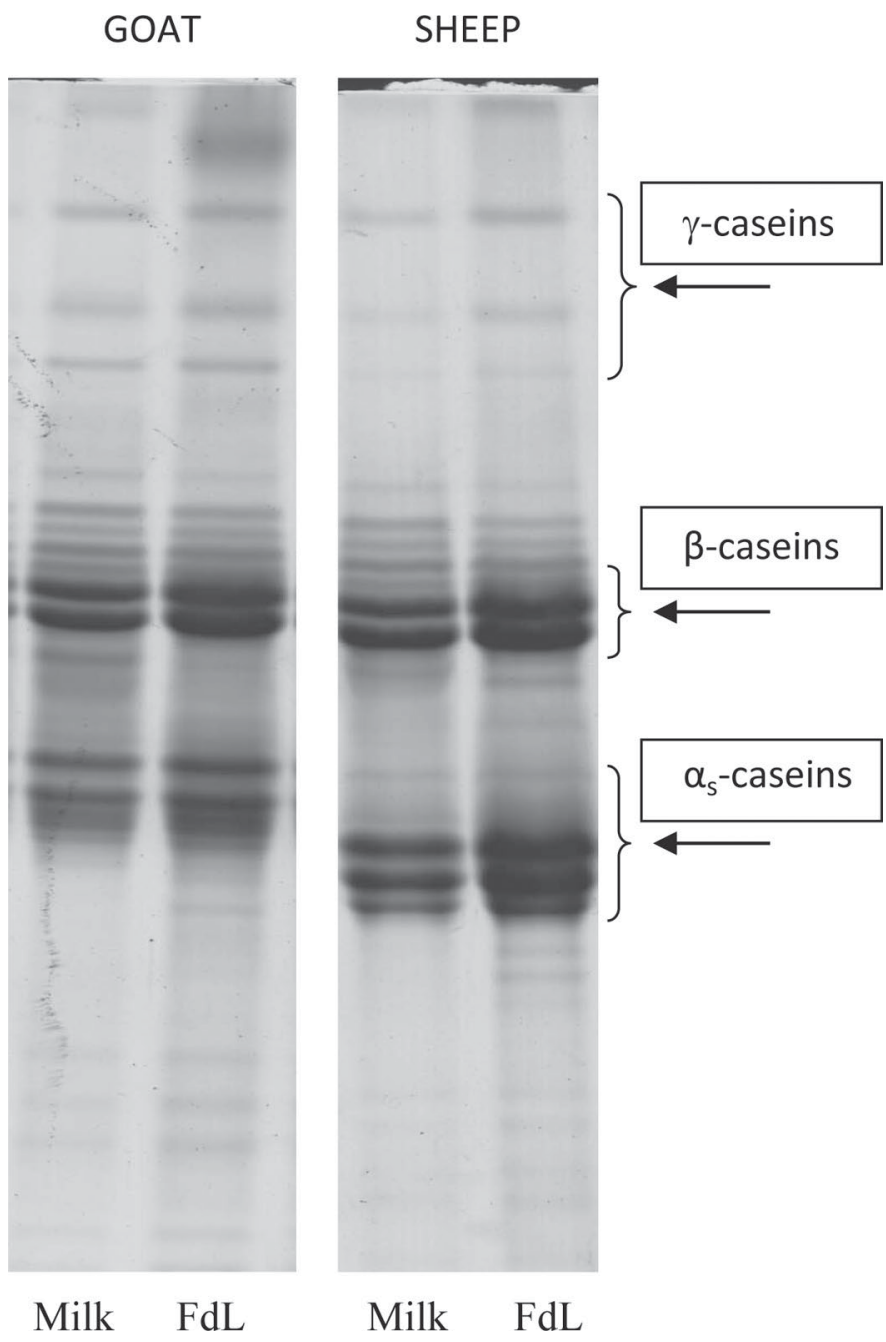

Figure 3. Urea-PAGE patterns of caseins in goat and sheep milks and Fior di latte (FdL; $1 \mathrm{~d}$ after production). 
FACCIA ET AL.

Table 7. Pathogen testing of sheep and goat Fior di latte, according to the European Union regulations ${ }^{1}$

\begin{tabular}{lcccc}
\hline Cheese & L. monocytogenes & $\begin{array}{c}\text { Salmonella } \\
\text { spp. }\end{array}$ & $\begin{array}{c}\text { CPS } \\
(\mathrm{cfu} / \mathrm{g})\end{array}$ & $\begin{array}{l}\text { E. coli, } \\
\text { (cfu/g) }\end{array}$ \\
\hline Sheep & - & - & 400 & $<10$ \\
Goat & - & - & $<100$ & $<10$ \\
\hline
\end{tabular}

${ }^{1}$ Listeria monocytogenes and Salmonella spp. were absent in $25 \mathrm{~g}$ of cheese; actual counts of coagulase-positive staphylococci (CPS) and $\beta$-glucoronidase-positive Escherichia coli are shown.

the pathogens listed in the European Union regulations was found in 25-g samples of cheese, and total coliform counts were low, as were the counts of total mesophilic bacteria and yeasts and molds. These findings may be ascribed to the good microbiological quality of the raw milk and the thermal effect of the stretching process. Nevertheless, pasteurization is recommended. No differences were found between goat and sheep Fior di latte, and as expected, the microbiota in both cheeses consisted mainly of the lactic acid bacteria added during cheesemaking. Pseudomonas spp. counts were similar to those commonly found in bovine high-moisture mozzarella (Sinigaglia et al., 2008; Faccia et al., 2013). It is essential to control the growth of these microorganisms during cheese storage to prolong shelf life, because they are important causes of quality alteration (Sinigaglia et al., 2008; Mastromatteo et al., 2014).

\section{Cheese Sensory Evaluation}

Appearance of the prototype cheeses was similar to that of cow milk Fior di latte, as can be seen in Table 8 . Perception of the white color, although not statistically significant, was more evident in the novel cheeses due to the low carotene concentration in goat and sheep milk (Park et al., 2007). A whiter color could be an advantage, because pure white is a basic requirement of mozzarella cheese (Jana and Mandal, 2011). The panelists provided a distinctive appearance descriptor for the 2 new types of Fior di latte - the term "porcelain," which described a shiny surface. As for the other groups of descriptors, the new cheeses were less similar to cow milk Fior di latte. In particular, characteristic "goaty" and "sheepy" odor and flavor were perceived at a high level of significance $(P<0.01)$ in goat and sheep milk

Table 8. Sensory evaluation of cow, goat, and sheep milk Fior di latte (hedonic scale 1-5)

\begin{tabular}{lccc}
\hline Attribute & Cow & Goat & Sheep \\
\hline External appearance & & & 5 \\
White & 4 & 5 & 4 \\
Translucent & 4 & 4 & 2 \\
Fibrous & 2 & 2 & 5 \\
Smooth paste & 5 & & $2^{* *}$ \\
Odor & 1 & $2^{* *}$ & 2 \\
Milk odor & 1 & 1 & 2 \\
Butter odor & 2 & 2 & 2 \\
Yogurt odor & & & 1 \\
Flavor during chewing & 2 & 2 & 1 \\
Acid & 1 & 1 & $1^{*}$ \\
Bitter & 1 & $3^{*}$ \\
Sweet & 2 & $3^{* *}$ & 2 \\
Salty & 1 & 2 & 2 \\
Milk flavor & 1 & & $2^{*}$ \\
Cream flavor & & 2 & 2 \\
Texture during chewing & 2 & $2^{*}$ & $1^{*}$ \\
Firm & 4 & 2 & 2 \\
Elastic & 2 & $1^{*}$ & $1^{*}$ \\
Cohesive & 2 & 2 & 2 \\
Jubbery & 2 & 0 &
\end{tabular}


cheeses, respectively. A more intense cream flavor and, for sheep milk cheese, a more distinct butter odor were perceived, but this result was not significant $(P>0.5)$. Differences in the score for "salty flavor while chewing" indicated lower perception in sheep and goat cheeses than in cow milk cheese. This could be due to the different salting procedure because the concentration of $\mathrm{NaCl}$ was not very different from that normally found in bovine Fior di latte (Minervini et al., 2012). Brine salting causes an uneven distribution of sodium chloride in the cheese paste, with the outer portion being more salted than the inner portion, which might explain the less salty flavor perceived by the panel. Distinctive flavor descriptors were "almond milk" (for goat cheese), and "walnuts" (for sheep cheese). Compared with cow milk Fior di latte, 3 texture descriptors - elastic, rubbery, and, for the sheep cheese, slippery — had lower or higher scores $(P<0.05)$. These differences are in line with the different behavior of the curds during stretching, which gave rise to a distinctive texture characteristic that the panelists described as "plastic."

\section{CONCLUSIONS}

The purpose of this study was to produce a prototypical Fior di latte cheese from sheep and goat milks. Not all processing technologies typically used to make cow milk Fior di latte mozzarella are suitable for sheep and goat milks because the latter milks have a higher protein content than cow milk. Although they were very similar in appearance to bovine Fior di latte, the cheeses obtained had some unique characteristics, displaying a specific identity in terms of flavor and texture. Given their characteristics and high cheesemaking yields, the new cheeses appear to have a promising market outlook and, if accepted by the consumers, they could offer interesting prospects for the small ruminant sector. Further investigations are underway to assess the shelf life of the new cheeses and to evaluate consumer acceptance.

\section{ACKNOWLEDGMENTS}

This work was supported by the Italian Ministry of Agricultural, Food and Forestry Policies - Observatory for Young Farmers (OIGA) grant "Messa a punto di schemi tecnologici per la produzione di mozzarella da latte ovi-caprino - S.Te.P.Mo.L.," and by Italian Ministry of University and Research-PON Research and Competitivity 00851 "Bioinnovazioni per produzioni lattiero-casearie ad elevato contenuto salutistico."

\section{REFERENCES}

Albenzio, M., A. Santillo, M. Caroprese, A. Braghieri, A. Sevi, and F. Napolitano. 2013a. Composition and sensory profiling of probiotic Scamorza ewe milk cheese. J. Dairy Sci. 96:2792-2800.

Albenzio, M., A. Santillo, M. Caroprese, D. Ruggieri, F. Napolitano, and A. Sevi. 2013b. Physicochemical properties of Scamorza ewe milk cheese manufactured with different probiotic cultures. J. Dairy Sci. 96:2781-2791.

Albenzio, M., A. Santillo, A. Trani, and M. Faccia. 2010. Maturing of ovine cheese: Influence of probiotic strain. J. Dairy Sci. 93:34873496.

Altieri, C., C. Scrocco, M. Sinigaglia, and M. A. Del Nobile. 2005. Use of chitosan to prolong mozzarella cheese shelf life. J. Dairy Sci. 88:2683-2688.

Andrews, A. T. 1983. Proteinases in normal bovine milk and their action on caseins. J. Dairy Res. 50:45-55.

AOAC International. 2000. Official Methods of Analysis. AOAC International, Washington, DC.

Candiano, G., M. Bruschi, L. Musante, L. Santucci, G. M. Ghiggeri, B. Carnemolla, P. Orecchia, L. Zardi, and P. G. Righetti. 2004. Blue silver: A very sensitive colloidal Coomassie G-250 staining for proteome analysis. Electrophoresis 25:1327-1333.

Carić, M. 1999. Ripened cheese varieties native to the Balkan countries. Pages 263-279 in Cheese: Chemistry, Physics and Microbiology. Vol. 2: Major Cheese Groups, P. F. Fox, ed. Aspen Publishers Inc., Gaithersburg, MD.

Comunian, R., A. Paba, E. S. Daga, I. Dupré, and M. F. Scintu. 2010. Traditional and innovative production methods of Fiore Sardo cheese: A comparison of microflora with a PCR-culture technique. Int. J. Dairy Technol. 63:224-233.

de Candia, S., M. De Angelis, E. Dunlea, F. Minervini, P. L. H. McSweeney, M. Faccia, and M. Gobbetti. 2007. Molecular identification and typing of natural whey starter cultures and microbiological and compositional properties of related traditional Mozzarella cheeses. Int. J. Food Microbiol. 119:182-191.

European Union. 2005. Commission Regulation 2073/2005. Microbiological criteria for foodstuffs. 22.12.2005. Off. J. L338/1.

Faccia, M., M. Mastromatteo, A. Conte, and M. A. Del Nobile. 2012. Influence of different sodium chloride concentrations on microbiological and physico-chemical characteristics of mozzarella cheese. J. Dairy Res. 79:390-396.

Faccia, M., M. Mastromatteo, A. Conte, and M. A. Del Nobile. 2013. Influence of the milk bactofugation and natural whey culture on the microbiological and physico-chemical characteristics of mozzarella cheese. J. Food Process. Technol. 4:1-7.

Faccia, M., A. Trani, and A. Di Luccia. 2009. Relationships between milk quality and acidification in the production of table mozzarella without starters. J. Dairy Sci. 92:4211-4217.

Folch, J., M. Lees, and G. H. Sloane-Stanley. 1957. A simple method for isolation and purification of total lipids from animal tissues. J. Biol. Chem. 226:497-509.

Gammariello, D., A. Conte, S. Di Giulio, M. Attanasio, and M. A. Del Nobile. 2009. Shelf life of Stracciatella cheese under modifiedatmosphere packaging. J. Dairy Sci. 92:483-490.

Hauff, S., and W. Vetter. 2009. Quantification of fatty acids as methyl esters and phospholipids in cheese samples after separation of triacylglycerides and phospholipids. Anal. Chim. Acta 636:229-235.

IDF. 1981. Milk: Determination of fat content. Butyrometer Gerber. IDF Standard 105. International Dairy Federation, Brussels, Belgium.

IDF. 1986. Cheese and processed cheese products: Determination of dry matter. IDF Standard 4. International Dairy Federation (IDF), Brussels, Belgium.

IDF. 1989. Determination of $\mathrm{pH}$. IDF Standard 115A. International Dairy Federation (IDF), Brussels, Belgium.

IDF. 1993. Milk: Determination of nitrogen content. IDF Standard 20B. International Dairy Federation (IDF), Brussels, Belgium. 
ISO. 1993. Sensory analysis - General guidance for the selection, training and monitoring of assessors-Part 1: Selected assessors. ISO Standard 8586-1. International Organization for Standardization (ISO), Geneva, Switzerland.

ISO. 1994. Sensory analysis - General guidance for the selection, training and monitoring of assessors-Part 2: Experts. ISO Standard 8586-2. International Organization for Standardization (ISO), Geneva, Switzerland.

ISO. 1996. Microbiology of food and animal feeding stuffs: Horizontal method for the detection and enumeration of Listeria monocytogenes. ISO Standard 11290-1. International Organization for Standardization (ISO), Geneva, Switzerland.

ISO. 1999. Microbiology of food and animal feeding stuffs: Horizontal method for the enumeration of coagulase-positive staphylococci (Staphylococcus aureus and other species). ISO Standard 6888-1. International Organization for Standardization (ISO), Geneva, Switzerland.

ISO. 2001. Microbiology of food and animal feeding stuffs: Horizontal method for the enumeration of beta-glucuronidase-positive Escherichia coli-Colony-count technique at $44^{\circ} \mathrm{C}$ using 5-bromo-4-chloro-3-indolyl beta-D-glucuronide. ISO Standard 16649. International Organization for Standardization (ISO), Geneva, Switzerland.

ISO. 2002. Horizontal method for the detection of Salmonella species. ISO Standard 6579. International Organization for Standardization (ISO), Geneva, Switzerland.

Jana, A. H., and P. K. Mandal. 2011. Manufacturing and quality of mozzarella cheese: A review. Int. J. Dairy Sci. 6:199-226.

Kilic, G. B., H. Kuleasan, I. Eralp, and A. G. Karahan. 2009. Manufacture of Turkish Beyaz cheese added with probiotic strains. Lebenson. Wiss. Technol. 42:1003-1008.

Mallatou, H., E. C. Pappa, and V. A. Boumba. 2004. Proteolysis in Teleme cheese made from ewes', goats' or a mixture of ewes' and goats' milk. Int. Dairy J. 14:977-987.

Mastromatteo, M., A. Conte, M. Faccia, M. A. Del Nobile, and A. V. Zambrini. 2014. Combined effect of active coating and modified atmosphere packaging on prolonging the shelf life of low-moisture Mozzarella cheese. J. Dairy Sci. 97:36-45.

Milanović, S., M. Kaláb, and M. Carić. 1998. Structure of Kashkaval curd manufactured from milk or UF retentate using enzymes of various origin. Lebenson. Wiss. Technol. 31:377-386.

Minervini, F., S. Siragusa, M. Faccia, F. Dal Bello, M. Gobbetti, and M. De Angelis. 2012. Manufacture of high-moisture mozzarella cheese by incorporation of probiotic lactobacilli. J. Dairy Sci. 95:508-520.
Molina, E., M. Ramos, and L. Amigo. 2002. Characterisation of the casein fraction of Iberico cheese by electrophoretic techniques. J. Sci. Food Agric. 82:1240-1245.

Morea, M., F. Baruzzi, and P. S. Cocconcelli. 1999. Molecular and physiological characterization of dominant bacterial populations in traditional Mozzarella cheese processing. J. Appl. Microbiol. $87: 574-582$.

Morrison, W. R., and L. H. Smith. 1964. Preparation of fatty acid methyl esters and dimethylacetals from lipid with boron fluoridemethanol. J. Lipid Res. 5:600-608.

Mucchetti, G., B. Bonvini, M. C. Remagni, R. Ghiglietti, F. Locci, S. Barzaghi, S. Francolino, A. Perrone, A. Rubiloni, P. Campo, M. Gatti, and D. Carminati. 2008. Influence of cheese-making technology on composition and microbiological characteristics of Vastedda cheese. Food Contr. 19:119-125.

Pagliarini, E., E. Monteleone, and I. Wakeling. 1997. Sensory profile description of mozzarella cheese and its relationship with consumer preference. J. Sens. Stud. 12:285-301.

Park, Y. W., M. Juarez, M. Ramos, and G. F. W. Haenlein. 2007. Physico-chemical characteristics of goat and sheep milk. Small Rumin. Res. 68:88-113.

Romano, P., A. Ricciardi, G. Salzano, and G. Suzzi. 2001. Yeasts from water buffalo Mozzarella, a traditional cheese of the Mediterranean area. Int. J. Food Microbiol. 69:45-51.

Scintu, M. F., and G. Piredda. 2007. Typicity and biodiversity of goat and sheep milk products. Small Rumin. Res. 68:221-231.

Shaker, R. R., A. Attlee, H. Kasi, T. M. Osaili, A. A. Al Nabulsi, and H. A. Ababneh. 2012. Comparison of the quality of low moisture mozzarella cheese made from bovine, ovine and caprine milks. J. Food Agric. Environ. 10:89-93.

Sinigaglia, M., A. Bevilacqua, M. R. Corbo, S. Pati, and M. A. Del Nobile. 2008. Use of active compound for prolonging the shelf-life of mozzarella cheese. Int. Dairy J. 18:624-630.

Trani, A., G. Gambacorta, P. Loizzo, G. Alviti, A. Schena, M. Faccia, L. Aquilanti, S. Santarelli, and A. Di Luccia. 2010. Biochemical traits of Ciauscolo, a spreadable typical dry-cured sausage. J. Food Sci. 75:C514-C524.

Veloso, A. C. A., N. Teixeira, and I. M. P. L. V. O. Ferreira. 2002. Separation and quantification of the major casein fractions by reverse-phase high-performance liquid chromatography and ureapolyacrylamide gel electrophoresis. Detection of milk adulterations. J. Chromatogr. A 967:209-218. 